\title{
Corela
}

Cognition, représentation, langage

$15-2 \mid 2017$

Vol. $15, n^{\circ} 2$

\section{Storytelling in French from France and French from Quebec}

Conceptualization of events

Natalia DANKOVA

\section{CpenEdition}

\section{Journals}

Édition électronique

URL : http://journals.openedition.org/corela/5051

DOI : $10.4000 /$ corela.5051

ISSN : 1638-573X

Éditeur

Cercle linguistique du Centre et de l'Ouest - CerLICO

Référence électronique

Natalia DANKOVA, «Storytelling in French from France and French from Quebec », Corela [En ligne],

15-2 | 2017, mis en ligne le 23 novembre 2017, consulté le 19 avril 2019. URL : http://

journals.openedition.org/corela/5051 ; DOI : 10.4000/corela.5051

Ce document a été généré automatiquement le 19 avril 2019

\section{cc)(1)(2)}

Corela - cognition, représentation, langage est mis à disposition selon les termes de la licence

Creative Commons Attribution - Pas d'Utilisation Commerciale - Partage dans les Mêmes Conditions

4.0 International. 


\title{
Storytelling in French from France and French from Quebec
}

\author{
Conceptualization of events
}

Natalia DANKOVA

\section{Introduction}

1 Most studies of language variation focus on the lexicon, pronunciation and morphology. Certain languages are recognised as having different forms in different continents, for example: British English, American English and Australian English, not to mention a number of new 'Englishes' emerging across the globe. The same is true for Spanish, when Castilian is compared with the varieties of the language spoken in Latin America. Variation in French is a relatively new field of study, since in the past there was greater interest in "deviation" from the norm - embodied by the French used in France - than in variation as a legitimate phenomenon.

In this study, we examine variation in French from a psycholinguistic perspective. Two varieties are compared: French spoken in France and French spoken in Quebec. The choice of these two varieties is based on the geographical distance that separates them, the distinct development of each variety and the presence of English in Quebec. The goal of the study is to ascertain whether speakers of the two varieties communicate different information when they are exposed to the events portrayed in the same stimulus material. When speaking of the information to be transmitted, we not only take into account the content of the story, but also information of a grammatical nature (verb tenses, use of passive or active structures, types of subordination) and of a lexical nature (different types of adverbs, the role of adjectives, the use of verbs of perception or of action). We also consider the organization of the information in a narrative text (the structure of the story, causal relationships between events, types of descriptions, etc.).

In his model of speech production, Levelt (1989) identifies three stages: conceptualization, formulation and articulation. In order to talk about an event which has occurred, the speaker must first understand what has happened and then make a 
choice about what to recount. So, understanding the occurrence, interpreting it and selecting the information to transmit are part of the first stage, that is, conceptualization. The generation of the preverbal message is the result of this first stage. This is a mental process that, according to Levelt, occurs independently of the speaker's language. During the next stage, the preverbal message is encoded with respect to the grammar, lexicon and phonology of the language being used. The last stage, the actual articulation of the message, at the phonological level, is not relevant to this study.

4 A number of studies on the acquisition of a second language (L2) have demonstrated that a learner's first language (L1) influences conceptualization by directing the attention of the speaker with regard to the selection of the information to be transmitted. For example, Russian speakers expressing themselves in Esperanto - a language in which transfer is specifically permitted - look for additional ways to express verbal aspect, a grammaticalized category present in Russian in each verbal form. These speakers turn to verbal prefixation by reproducing the mode of formation of the perfective aspect in L1. They also use lexical means, such as the adjectives jam (yet), subite (suddenly) or finfine (finally), to strengthen the perfective aspect. This occurs not only in the conjugated forms but in the infinitive as well. The influence of the L1 also manifests itself in the expression of temporal relationships through the use of adverbs in Esperanto spoken by Italian, French (from France), and Russian speakers. A comparison of the productions in Esperanto L2 with productions in L1 - Italian, French and Russian respectively - brings the preferences of each group of subjects to light (Dankova, 1997, 1998, 1999, 2001, 2009b).

5 Each language and its grammaticalized categories impose choices on its speakers and each speaker must choose from the various options offered. In investigating the use of the English articles in introduction of objects in to a discourse, Du Bois (1980) states:

In particular, noun phrases frequently fail to receive definite marking, not because they do not refer to an identifiable object, but because they simply do not refer. [...] Speakers exert a considerable degree of control over their choice of alternatives. With the curiosity of the addressee in mind, the speaker makes judgments as to the salience of tracing an object's identity. (Du Bois, $1980: 272$ )

6 Studies by Slobin $(1991,1996,2003)$, who analyzes the expression of motion events in languages, emphasize the orientation of the speaker's attention when it comes to reporting dynamic events and static descriptions.

7 Studies on the acquisition of L2 have revealed the importance of thinking in the second language : a learner at a very advanced level who has mastered the grammatical and lexical rules of the L2, but who continues to think and organize information according to the rules of the L1, is not considered a native speaker (cf. Lambert, 1997, Carroll and Von Stutterheim, 1997 and 2002, Carroll and Lambert, 2003).

8 There are numerous studies comparing the expression of time in different languages that are more or less distant typologically, and which are based on the productions of native speakers, bilinguals and/or learners (cf. Izutsu and Izutsu, 2016, Borchers, 2016, Saddour, 2012, Yoshioka and Hilbernk-Schulpen, 2012).

9 Engemann, Harr and Hickmann (2012) note that in bilinguals' productions in French

[...] in addition to some qualitative divergences from monolingual French usage that bear some resemblance to L2 transfer phenomena, bilinguals, motion verbalizations also differ quantitatively from monolinguals in terms of how frequently the verb and other devices are used to encode various information types. (Engemann, Harr and Hickmann, 2012 : 277) 
Many researchers agree that each language has its own way of conceptualizing time and events and that the grammatical and lexical categories of a language influence the conceptualization. Is conceptualization different in the varieties of a language? If so, how do these differences manifest themselves and what are the reasons for this variation?

In this study, we attempt to shed light on these differences. As a hypothesis, we consider that the distinct evolution of the two varieties, the socio-cultural context and the impact of English, in the case of the French spoken in Quebec, are potential sources of variation (cf. also Dankova, 2002 and 2009a). No other study deals with temporality in varieties of a language in the same perspective.

\section{Corpus}

12 Subjects were selected and divided into three groups: Francophones from France, Francophones from Quebec and Anglophone Canadians. The subjects range from 19 to 40 years of age and come from an urban area (Paris, Quebec City/Gatineau or Ottawa, respectively.) All of the subjects are unilingual (according to subjects confirmation): while some have minimal knowledge of an L2 (French or English) based on what they learned in a school setting, they are, for all intents and purposes, non-functional in this language. The group of Anglophones was recruited in order to examine the influence of English on conceptualization in the French spoken in Quebec. For this purposes of this study, 20 subjects were selected for each group.

13 The corpus is composed of two types of oral stories: stories based on a series of images, Cat Story (Hickmann, 1982, cf. Appendixes), and stories based on an animated film, Quest. This text-free film follows a character searching for water to drink. During his quest, he must confront obstacles in a desert of sand, then in a desert of paper and finally in a desert of rock. Every time he gets close to his goal, the world crumbles; he falls into a new world and must then face new obstacles.

14 The corpora of Cat Story in French from France and in French from Quebec are of equivalent lengths: approximately 4000 words each. The corpus of Cat Story in English contains approximately 5500 words. As for the stories based on the film Quest, the corpora contain the following numbers of words: French from France, approximately 12200 words ; French from Quebec, approximately 13300 words; and English, approximately 12600 words.

\section{Protocol}

15 The data were gathered following a very strict protocol. The goal of the study was not revealed to any of the participants, who were each recorded separately.

Each participant was invited to watch the film Quest and thereafter to describe its content. After each part, the film was stopped to allow the participant to tell what is going on one at a time so as to avoid confusion between the various parts of the film. No time limit was imposed. Once finished with one part, the participant continued the viewing of the next part. This way of proceeding was explained to the participants ahead of the actual viewings. As explained to them, the participants were expected to focus on 
what was going on in the film and not to criticize it. As well, overly philosophical comments were not encouraged.

As for the Cat Story, each participant was invited to look carefully at the pictures and to tell a story as if he/she were speaking to a child.

The use of common stimulus material simplifies the comparison of the narratives produced by the different groups of subjects. On a cultural level, the supports are neutral and give no advantage to either of the groups and that do not contain explicit visual or sound elements specific to a particular culture that could be understood or interpreted differently according to the participant's culture and language.

\section{Results}

19 The analyses focus on the treatment of the information provided by the visual stimuli : What types of information are selected and encoded in the stories? How are the events in the stimuli interpreted? Which linguistic means are favoured by the subjects of the three groups?

In Cat Story, subjects are inclined to interpret the images by projecting intentions onto the three protagonists - the bird, the cat and the dog - in their description of the elements of the story. The images present the state of events at different stages in the story and it is up to the narrators to establish the causal links between these events. While it is possible for the narrators to limit themselves to describing the images (for example, there is a nest, the bird flies away, then a cat arrives, etc.) without adding any additional information, the subjects produced a story, as it was requested of them (as opposed to providing a simple description). For the adults, this translated into a complex text in which different types of information are combined (such as static description of location, the introduction of characters, the description of events, the speaker's interpretation of the events, and a resolution to the story).

21 The events in all of the stories remain the same, since they are based on the same stimuli. However, the interpretation of these events demonstrates very different attitudes. First, we focused on the representation of the bird and the reasons given for its departure from the nest (image 2 in the series). The subjects from France were unanimous: the bird leaves its nest with the goal of finding food for its fledglings. While the bird's fear of the cat is mentioned by three of these subjects, it is not identified as the reason for the bird's departure. On the other hand, in 8 of the 34 stories by Quebecers recorded and analyzed, the bird leaves because of its fear of the cat. Two subjects from Quebec talk about the bird being hungry. In most of the English stories, the bird sets off to find food for its babies.

Even though the search for food remains the principal reason for the bird's departure, some French-speaking and English-speaking Canadians explain it by saying that the bird needs to build or renovate its nest, a pattern that occurs as in the stories by 3 Anglophone as by 4 Francophone subjects. In all the stories the French always describe the bird as a maternal figure, despite the fact that the word oiseau 'bird' is of the masculine gender in French. A few Canadians refer to the bird as being a male of the species :

1) Alors monsieur Maurice a pour nid la branche d'un arbre, il était en train de bâtir peu à peu son nid (Carole-Anne)

'So Mr. Maurice has the branch of a tree as a nest and he was in the process of building his nest bit by bit' 
2) and so Bob was at home babysitting the kids and he noticed there was a little bit of a home renovation project in the nest because he saw that maybe he/he could go \&um/\&uh/ \&uh you know... expand a little bit (Walter) French subjects compared to those told by the Canadian subjects. The arrival of the cat is a key event in the story. In French from France, the cat's arrival happens suddenly. Subjects use adverbials such as tout à coup 'all of a sudden' or soudain 'suddenly' (in 13 stories). The change of the verb tense used in the narration also highlights the unexpected nature of the event : in stories told in the past tense, a switch to the present tense is systematic. This behaviour has often been observed (Hickmann \& Roland, 1992, Chuquet, 2000). In the stories in French from Quebec and in English, the bird sometimes notices the arrival of the cat before leaving and in these cases, the arrival of the cat is not described. Unlike the French subjects who describe the arrival of the cat as something abrupt and unexpected, Canadian subjects describe the movements of the cat as being slow or discreet :

3) Mais tranquillement le chat s'approche

'But slowly and gently the cat approaches'

4) Un chat rôdait par là

'A cat was on the prowl around there'

5) A cat strolls along

6) The cat creeps up underneath

Contrary to the Francophone subjects from Quebec and the Anglophones who both describe the arrival of the cat by using verbs of motion, the French subjects also use verbs of visual perception. In other words, the character is presented, in this case, from the narrator's point of view :

7) Et puis on voit un chat qui s'approche

'And then we see a cat approaching'

8) Et tout à coup un chat apparaît

'And all of a sudden a cat appears'

The use of different types of psychological verbs in the stories deserves special attention. In analyzing the verbs, we consider the following categories : verbs of perception such as regarder 'to look', voir 'to see', entendre 'to hear', and verbs of cognition that describe mental representation and activity such as comprendre 'to understand', penser 'to think', décider 'to decide', and se rendre compte 'to realize'. Verbs of visual or auditory perception are frequent in the stories of the French subjects, compared to those in the stories of subjects from Quebec (Tables 1 and 2). As for verbs of cognition, they are more frequent in the English stories than in the French stories and their rates are higher in the corpus from Quebec than in the corpus from France. The number of verbs indicated in Table 1 does not include usages such as tu vois 'you see' or tu sais 'you know' that have a purely discursive value (cf. example 2).

Table 1 Psychological verbs (Cat Story) (occurrences)

\begin{tabular}{|l|l|l|l|}
\hline & France & Quebec & English (Canada) \\
\hline Verbs of perception & 80 & 46 & 74 \\
\hline Verbs of cognition & 23 & 36 & 58 \\
\hline
\end{tabular}




$$
\chi^{2}=13.926 \mathrm{df}=2 \mathrm{p}<0.01
$$

French France vs French from Quebec $: \chi 2=9.782 ; \mathrm{p}<0.01 ; \mathrm{df}=1$

The presence of a psychological verb introduces an additional piece of information. In $9 \mathrm{~b}$, for instance, the subject simultaneously expresses the ideas of movement, grimper 'to climb', and intention, decider 'to decide' :

9) (a) Le chat grimpe à l'arbre

'The cat climbs up the tree'

(b) Le chat décide de grimper à l'arbre

'The cat decides to climb up the tree'

Table 2 Psychological verbs (Quest) (occurrences)

\begin{tabular}{|l|l|l|l|}
\hline & France & Quebec & English (Canada) \\
\hline Verbs of perception & 96 & 78 & 361 \\
\hline Verbs of cognition & 18 & 22 & 87 \\
\hline
\end{tabular}

\section{$\chi 2=1.3751 .375<5.5991 \mathrm{df}=2 \mathrm{p}=0.05$}

The chi-square test is inconclusive. The categorical variables are independent.

In the stories based on Quest, the number of psychological verbs is higher for the subjects from France than for those from Quebec (Table 3). The use of psychological verbs also conveys a greater level of subjectivity in the presentation of events and descriptions, as though the narrator were seeing things through the eyes of the character, all the while projecting onto it intentions, feelings and thoughts :

10) Il voit une accumulation d'eau et d'humidité sur des feuilles / alors il s'approche pour essayer de voir / parce qu'on sent qu'il a soif

'He sees an accumulation of water and humidity on the sheets /

so he moves nearer to try to see / because we feel that he is thirsty'

In all three groups, the expression of visual perception prevails over auditory perception or perception of touch and the total of the verb describing thòe visual perception is higher in French from France than in French from Quebec (Tables 3 and 4) :

Table 3 Verbs of perception (Quest) (occurrences and \%)

\begin{tabular}{|l|l|l|l|}
\hline & France & Quebec & English (Canada) \\
\hline Visual perception & 65 & 52 & 302 \\
$67.7 \%$ & $66.66 \%$ & $83.7 \%$ \\
\hline Auditory perception & 23 & 20 & 51 \\
\hline Perception of touch & 8 & $25.64 \%$ & $14.1 \%$ \\
\hline Total (100\%) & $8.3 \%$ & $7.7 \%$ & $2.2 \%$ \\
\hline
\end{tabular}


$\chi^{2}=21.35 \mathrm{df}=4 \mathrm{p}<0.001$

Table 4 Verbs of perception (Cat Story) (occurrences and\%)

\begin{tabular}{|l|l|l|l|}
\hline & France & Quebec & English (Canada) \\
\hline Visual perception & $\begin{array}{l}78 \\
97.5 \%\end{array}$ & $\begin{array}{l}46 \\
100 \%\end{array}$ & $\begin{array}{l}74 \\
100 \%\end{array}$ \\
\hline Auditory perception & 2 & 0 & 0 \\
\hline Perception of touch & 0 & 0 & 0 \\
\hline Total (100\%) & 80 & 46 & 74 \\
\hline
\end{tabular}

The chi-square test cannot be used because more than $20 \%$ of the cells do not content any occurrence.

In the stories of Quest, the total of the verb describing the visual perception is particularly high in English: Anglophones frequently use the verb to see (102 occurrences) to introduce descriptions. The following examples describe the scene in which the protagonist is confronted with the sheets of paper blowing around in the desert of paper :

11) We see paper flying around

12) And so we see him covered by this piece of paper

13) You see tornados of paper

14) And I see that it's paper that's flying about

15) And we see kind of like tornado

In the same circumstances, the Francophones use expressions of presentation such as c'est 'it is' and il y a 'there is', which are much more frequent in the corpus from Quebec than in the corpus from France :

Table 5Expressions of presentation (Quest) (occurrences)

\begin{tabular}{|l|l|l|}
\hline & France & Quebec \\
\hline c'est "it is" & 37 & 83 \\
\hline ily a "there is/are" & 57 & 74 \\
\hline Total & 94 & 157 \\
\hline
\end{tabular}

$37 \mathrm{X}^{2}=4.297 \mathrm{df}=1 \mathrm{p}<0.05$

16) Il y a des feuilles de papier qui volent 'There are sheets of paper flying'

17) Il y a du papier qui tourne comme une tornade 'There is paper spinning like a tornado'

18) Là, c'est uniquement des feuilles de papier qui volent

'There, it is only sheets of paper that fly' 
19) C'est comme des feuilles de papier qui font le sol

'It's like sheets of paper make up the ground'

the fall and its direction. In English, the verb may be followed by down, in, through, etc. (cf Slobin, 1996, on the subject of the use of English verbs with verb particles in narrative texts in comparison with Spanish texts). English subjects turn to this means systematically : in $95 \%$ of the cases, the description of the fall includes the expression of the direction (cf. Table 6) :

Table 6 Character's falls (Quest) (occurrences and \%)

\begin{tabular}{|l|l|l|l|}
\hline & France & Quebec & English (Canada) \\
\hline Reference to the direction & $\begin{array}{l}23 \\
42 \%\end{array}$ & $\begin{array}{l}45 \\
60 \%\end{array}$ & $\begin{array}{l}70 \\
95 \%\end{array}$ \\
\hline No reference to the direction & 32 & 30 & 4 \\
$58 \%$ & $40 \%$ & $5 \%$ \\
\hline Total (100\%) & 55 & 75 & 74 \\
\hline
\end{tabular}

$\mathrm{X}^{2}=43.322 \mathrm{df}=2 \mathrm{p}=0.000$

French France $v s$ French from Quebec $: \chi 2=4.205 ; \mathrm{p}=0.0403 ; \mathrm{df}=1$

French from Quebec vs English (Canada) $: \chi 2=25.311 ; \mathrm{p}=0.0000 ; \mathrm{df}=1$

French from France $v$ s English (Canada) $: \chi 2=43.68 ; p=0.0000 ; \mathrm{df}=1$

As for the French stories, this pattern is inverted: Quebecers prefer to combine the expression of the fall with that of the direction of the fall in $60 \%$ of the cases, while the French do so only $42 \%$ of the time, for example :

20) Les feuilles de papier craquent et il tombe

'The sheets of paper crack and he falls'

21) Il est aspiré par le sable

'He is sucked up by the sand'

In the French corpus, the most frequently-used structure is tomber dans qqch. ('to fall into something') :

22) Il tombe dans un trou

'He falls into a hole' 
23) Il tombe dans un autre univers

'He falls into another universe'

24) Il tombe dedans

'He falls into it'

25) Il retombe encore une fois dans le vide

'He falls once more into emptiness' structures, but the choice between presenting the character as being active or inactive cannot simply be explained by the choice to use a passive structure, as shown in example 38 :

38) Et donc il trempe ses mains dans cette feuille humide qui se froisse et se déchire et l'emporte en profondeur

'And so he dips his hands into this humid sheet that wrinkles and rips and takes him deep away' 
Although in the majority of cases, the character is described as being involved and aware in his falls (cf. Table 7), subjects from Quebec demonstrate the highest rate $(80 \%)$, compared to the French (64\%). The most frequently used verb in these cases is tomber 'to fall' in French and to fall in English. In English, the character is presented as being involved and aware of the falls in 54 cases $(73 \%)$ and as being unconscious and inactive in 20 cases $(27 \%)$. The differences observed between the French corpora show once again that despite the fact that both groups may draw from the same means of expression available in French, the speakers from Quebec and from France proceed differently in order to present information. This allows us to speak of different conceptualization in the two varieties of French.

Table 7 Character's description in the falls (Quest) (occurrences and \%)

\begin{tabular}{|l|l|l|l|}
\hline & $\begin{array}{l}\text { The character is involved and } \\
\text { aware }\end{array}$ & $\begin{array}{l}\text { The character is unconscious and } \\
\text { inactive }\end{array}$ & $\begin{array}{l}\text { Total (100\% } \\
\text { France } \\
35\end{array}$ \\
\hline $64 \%$ & $\begin{array}{l}20 \\
36 \%\end{array}$ & 55 \\
\hline Quebec & 60 & 15 & 75 \\
\hline
\end{tabular}

$\mathrm{X}^{2}=4.319 \mathrm{df}=1 \mathrm{p}=0.0376$

A greater lexical variety is observed when the character is described as being unconscious and inactive : il est aspiré 'he is sucked up' / englouti 'engulfed' / enseveli 'inhumed', avalé 'swallowed', enfoui 'buried'. Not only is the fall mentioned, with or without a direction, but the way of falling is also described:

39) Et finalement il est englouti par le sable

'And finally he is engulfed by the sand'

40) Il est enseveli par les sables mouvants

'He is inhumed by the quick sand'

41) Et petit à petit il est aspiré par le sable, et donc il est avalé

'And little by little he is sucked up by the sand and is therefore swallowed'

51 We consider that the use of passive structures occurs out of the necessity to assemble many types of information (the fall of the character that is the result of the influence of the environment, the way of falling, the direction). In this case, the conceptual method differs according to group.

In the second sequence of the film Quest, the character finds himself in a world of paper, where there are sheets of paper blowing in the wind, forming a tornado. The character is attacked by these sheets. He struggles against those that fly in his face and is eventually knocked over. In this passage, there is an interaction between the character and the elements of the environment. In which way do the subjects of the three groups approach the elements appearing in the film? Which aspects attract their attention?

The analyses reveal different approaches when it comes to mentioning the wind and the perspective adopted in the description of the interaction between the sheets of paper and the protagonist. The Francophones in both groups focus their attention on the wind, which they describe independently of the other elements : 
42) Il y a du vent dans ce monde

'There is wind in this world'

43) Il y a un vent qui souffle

'There is a wind that blows' descriptions of the events and the situations
Anglophones tend to be more dynamic than static:

51) And there's a slight breeze blowing some of the paper around

52) There's a lot of wind between the sheets of paper and the character, varies from one group to another. The narrator is faced with three possibilities : first, to mainly describe the sheets of paper that attack the character; second, to place the emphasis on the actions of the character around which the entire film unfolds; and third, alternate between the two first possibilities. Table 8 summarizes the patterns observed in the corpus. The number of 
occurrences illustrates the number of times this interaction is evoked and does not take into consideration the other events of the sequence.

Table 8 Interaction between the sheets of paper and the character (Quest) (occurrences)

\begin{tabular}{|l|l|l|l|}
\hline & France & Quebec & English (Canada) \\
\hline Sheets of paper & 25 & 10 & 43 \\
\hline Character & 7 & 9 & 14 \\
\hline
\end{tabular}


produced by speakers of different mother tongues, each of the varieties of French has its own way of allowing speakers to consider the selection and the organization of information. Thus, the attention of speakers from France and from Quebec is held by different elements and the same elements contained in the stimulus material are treated in a specific way in each of the varieties.

Although the linguistic possibilities remain identical - rare exceptions aside (it is not about two different languages) - the choice of these means made by the speakers of the two varieties shows divergences in conceptualization. This is especially apparent in the interpretation of the events represented in the stimulus material and the establishment of causal links, and the distribution of the narrator's attention.

The comparison between stories in French from Quebec and in Canadian English allowed for the discovery of similarities in some of the analyzed cases. Nevertheless, the differences observed in the two varieties of French are not exclusively the product of the influence of English on French from Quebec, since the manifestation of this influence is sporadic and does not affect the productions in French from Quebec as a whole; French already offers numerous possibilities of expression from which speakers may choose. The phenomenon Slobin $(1991,1996)$ refers to as rhetorical style, which characterizes each language, also manifests itself in the two varieties of French observed, but less so than in the case of two distinct languages, since the means of expression remain fundamentally the same. Thus, in speaking of the differences in the two varieties of French, we consider the preferences of the speakers from France and from Quebec, which gravitate toward different means.

\section{Appendixes}



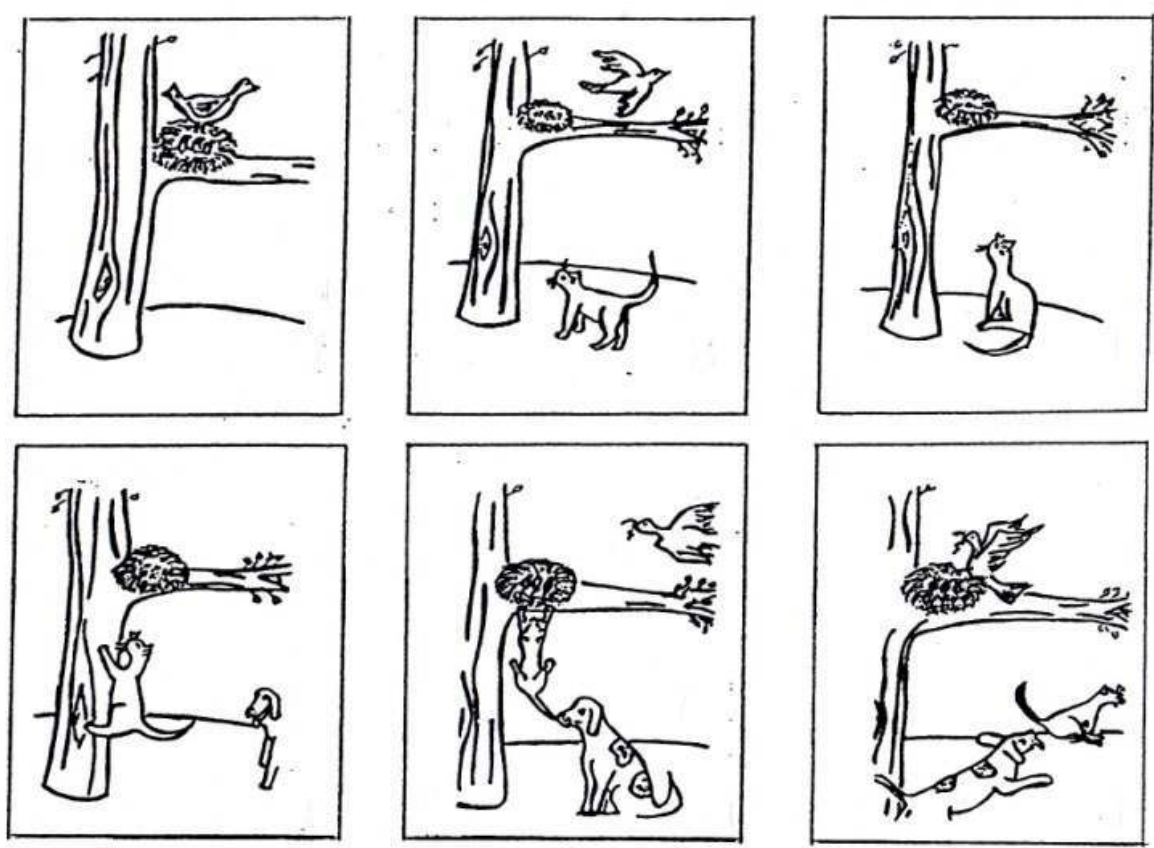

Quest (1996) by Thomas Stellmach (production) and Tyron Montgomery (direction) (Germany). Available at : http://www.youtube.com/watch?v=uTyev60aThg

Still of the character from Quest, the film used as a support for this study.

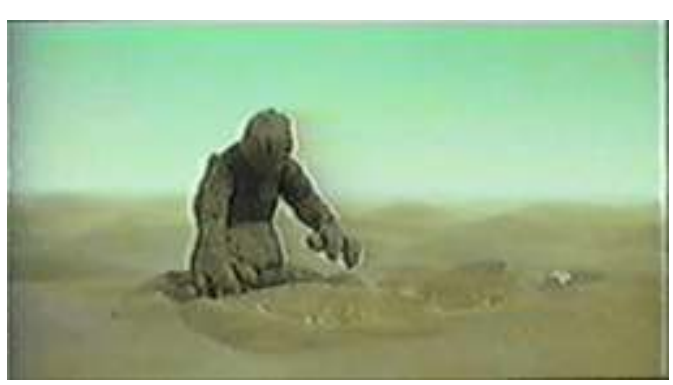

\section{Story produced on the basis of Cat Story (France)}

il y a un petit piaf qui a des petits oiseaux, des petits oisillons / et il faut évidemment les nourrir donc abandonner le nid / soudainement il y a un chat qui apparait / il aperçoit les petits oiseaux gazouiller dans le nid / il repère les lieux / comment y accéder par exemple / il grimpe tant bien que mal / et de là il y a un chien qui l'observe, un gros chien, un gros molosse / et presqu'en arrivant à la destination, c'est-à-dire au nid quoi / le chien l'attrape par la queue / il perd l'équilibre / il tombe /il s'enfuit/les oiseaux sont sauvés

'there is a little birdie that has little birds, little fledglings / and naturally the bird has to feed them and therefore abandon the nest / suddenly there is a cat that appears / he catches sight of the little birds chirping in the nest / he examines his surroundings / how could he get there for example / he struggles to climb / and from there there is a dog watching him, a big dog, a great big dog / and just as he is arriving at his destination, that 
is the nest, of course / the dog catches him by the tail / he loses his balance / he falls / he runs away / the birds are saved'

\section{Story produced on the basis of Quest (Quebec, Canada)}

donc après avoir été engouffré par les sables / on s'aperçoit que le personnage tombe du ciel dans un autre univers un autre monde / et puis il tombe dans un univers où est-ce qu'il y a juste du papier / donc tout est fait en papier / c'est une grande lande déserte / mais de papier avec du vent / puis bon des papiers qui partent au vent puis des petites tornades de papier un peu partout / puis euh le personnage a tombé dans ce monde-là / se relève / regarde autour de lui / puis réentend encore le bruit le bruit de l'eau / s'avance / et puis tombe sur un endroit où est-ce que c'est mouillé / puis on voit / que y a une goutte qui arrive sur cet endroit là / donc là il s'approche / met ses mains / essaie de toucher d'avoir de l'eau / met ses mains au ciel / parce que bon il se dit / il y a une goutte d'eau / qui tombe / il doit y avoir de l'eau qui va lui tomber dans les mains / et puis de frustration commence à tâter le sol / parce que il y a pas d'eau / le papier se déchire / parce que il est très certainement mouillé à cause de l'eau / puis il tombe encore une fois / il se fait engouffrer par le trou

'so after having been devoured by the sands / we realize that the character falls from the sky into another universe another world / and then he falls into a universe where there is only paper / so everything is made out of paper / it's a great deserted moor / but of paper and wind / and well papers that blow away in the wind and little tornados of paper more or less everywhere / and the \&uh character fell into that world there / gets back up / looks around him / then hears the sound the sound of water again / moves forward / and then happens upon a place where it's wet / then we see / that there is a drop that lands on this very place / so then he gets closer / puts his hands / tries to touch to get some water / raises his hands to the sky / because well he tells himself / there is a drop of water / that is falling / there must be some water that will fall into his hands / and then out of frustration begins to feel the ground / because there is no water / the paper rips / because it is most certainly wet because of the water / so he falls once again / he is devoured by the hole'

\section{BIBLIOGRAPHIE}

Borchers D. (2016). Marking anteriority, perfect and perfectivity in languages of mainland Southeast Asia - concepts, linguistic area. In Conceptualization of Time, B. LewandowskaTomaszczyk (ed). p. 243-270. Amsterdam : Benjamins.

Carroll, M. \& M. Lambert (2003). Information structure in narratives and the role of grammaticalized knowledge : a study of adult French and German learners of English. In Information Structure, Linguistic Structure and the Dynamics of Acquisition, Ch. Dimroth and M. Starren (eds), p. 267-288. Amsterdam : Benjamins.

Carroll, M. \& Ch. Von Stutterheim (1997). Relations entre la grammaticalisation et conceptualisation et implication sur l'acquisition d'une langue étrangère. AILE 9, p. 83-115. 
Carroll, M. \& Ch. Von Stutterheim (2002). Typology and information organization : the question of perspective taking and language-specific effects in the construal of events. In Typology and Second Language Acquisition, A. Ramat (ed.), p. 356-402. Berlin : De Gruyter.

Chuquet, H. (2000). L'alternance passé-présent dans le récit : contraintes de traduction du français vers l'anglais. Meta XLV, 2, p. 249-262.

Dankova, N. (2009a). Variétés de français : conceptualisation et sélection de l'information à transmettre. In Le français d'ici, F. Martineau, R. Mougeon, T. Nadasdi \& M. Tremblay (eds.), p. 15-35. Toronto : Éditions du GREF.

Dankova, N. (2009b). Temporality in Spoken Esperanto. Esperantologio/Esperanto Studies, 4, p. 43-60. Available at : http://www2.math.uu.se/esperanto/ees4.pdf.

Dankova, N. (2002). Conceptualisation et expression du temps en français québécois et en français de France. Langue et Linguistique, 28, p. 45-70.

Dankova, N. (2001). L'espéranto. Du mythe à la réalité. In Actes des XV Journées de linguistique, M.J. Goulet (ed.), p. 97-106. Québec : Université Laval, CIRAL.

Dankova, N. (1999). Espéranto. De ça n'a pas marché à comment ça marche ou langue internationale à plusieurs facettes culturelles. Dialogos Hispanicos 23, p. 439-453. Amsterdam : Rodopi.

Dankova, N. (1998). Transfert en espéranto. L'influence de la langue maternelle et la morphologie verbale. In Domaines de la recherche en linguistique appliquée, T. Carlevaro (ed.), p. 142-167. Bellinzona : H. Dubois.

Dankova, N. (1997). Transfert. Marquage temporo-aspectuel et adverbes de temps. In Views on the Acquisition and Use of a Second Language, L. Diaz and C. Perez (eds), p. 171-176. Barcelona : Universitat Pompeu Fabra.

Du Bois, J. (1980). Beyond definiteness : The trace of identity in discourse. In W. L. Chafe (ed.), The Pear Stories: Cognitive, Cultural, and Linguistic Aspects of Narrative Production, p. 203 - 274. Norwood, $\mathrm{NJ}:$ Ablex.

Engemann, H., A.-K. Harr \& M. Hickmann (2012). Caused motion events across languages and learner types : A comparison of bilingual first and adult second language acquisition. In Space and Time in Languages and Cultures : Linguistic Diversity, L. Filipovic, K. M. Jaszczolt and K. Jaszczolt (eds), p. 263 - 287. Amsterdam : Benjamins

Hickmann, M. \& F. Roland (1992). Déterminants sémantiques et pragmatiques dans l'acquisition du temps et de l'aspect : étude comparative du français, de l'allemand et de l'anglais. Lyon : Réseau Européen de Laboratoires sur l'acquisition des langues.

Hickmann, M. (1982). The Development of Narrative Skills : Pragmatic and Metapragmatic Aspects of Discourse Cohesion. PhD dissertation, University of Chicago.

Hickmann, M. (2003). Children's Discourse : Person, Time, and Space across Languages. Cambridge : CUP.

Izutsu, K \& M. N. Izutsu (2016). Temporal scenery : Experiential bases for deictic concepts of time in East Asian languages. In B. Lewandowska-Tomaszczyk (ed), Conceptualization of Time. p. 207 242. Amsterdam : Benjamins.

Lambert, M. (1997). En route vers le bilinguisme. AILE 9, p. 147-172.

Lambert M., Carroll, M. \& Ch. Von Stutterheim (2003). La subordination dans les récits d'apprenants avancés francophones et germanophones en anglais. AILE 19, p. 41-70.

Levelt, W. (1989). Speaking. From Intention to Articulation. London : MIT Press. 
Saddour, I. (2012). Expressing simultaneity using aspect : A comparison of oral productions in French L1, Tunisian Arabic L1 and French L2 by Tunisian learners. In Space and Time in Languages and Cultures : Linguistic Diversity, L. Filipovic, K. M. Jaszczolt and K. Jaszczolt (eds), p. 325 - 347. Amsterdam : Benjamins.

Slobin, D. I. (2003). Language and thought online : Cognitive consequences of linguistic relativity. In Language in mind : Advances in the Study of Language and Thought, D. Gentner and S. GoldinMeadow (eds), p. 157-192. Cambridge : MIT Press.

Slobin, D. I. (1996). Two ways to travel : Verbs of motion in English and Spanish. In Grammatical Constructions : Their Form and Meaning, M. Shibatani and S.A. Thompson (eds), p. 195-219. Oxford : Clarendon Press.

Slobin, D. I. (1991). Learning to think for speaking. Native language, cognition and rhetorical style. Pragmatics $1 / 1$, p. 7-26.

Yoshioka K. \& B. Hilberink-Schulpen (2012). The role of grammar in the conceptualization of 'progression' : A comparative analysis of Dutch and Japanese event descriptions. In Space and Time in Languages and Cultures : Linguistic Diversity, L. Filipovic, K. M. Jaszczolt and K. Jaszczolt (eds), p. 417 - 435. Amsterdam : Benjamins.

\section{RÉSUMÉS}

Cette étude analyse la conceptualisation des évènements et l'organisation de l'information à transmettre dans des textes narratifs oraux en français de France et en français québécois ayant comme support une série d'images et un film muet. Les locuteurs français et québécois s'attardent à des éléments différents et organisent leurs récits différemment. Nos analyses témoignent d'une différence dans les choix linguistiques des francophones des deux groupes (types de verbes, structures actives ou passives, présentation de personnages comme étant actifs ou inactifs, etc.) et d'une attitude particulière que les locuteurs de chaque groupe adoptent face aux informations contenues par les supports, ce qui nous amène à conclure que la conceptualisation des évènements diffère dans les deux variétés de français.

This study examines the conceptualization of events, and the organization of information to be transmitted, in oral narrative texts produced in French from France and from Quebec. When confronted with the same stimulus material (a series of images and a text-free film), speakers from France and Quebec focus their attention on different elements and organize the information in their stories differently. The analyses also reveal diversity in the linguistic choices of the Francophones of each group (verb types, active and passive structures, presentation of characters as being active or inactive, etc.) and show that, beyond the words they use, each group demonstrates a particular attitude with regard to the information presented by the supports, which points to different conceptualization in the two varieties of the language.

INDEX

Mots-clés : Variétés de français, Conceptualisation des évènements, Français québécois, Analyse du discours, Récits oraux

Keywords : Varieties of French, Conceptualization of events, French from Quebec, Discourse analysis, Storytelling 
AUTEUR

NATALIA DANKOVA

Université du Québec en Outaouais 